\title{
STRATEGI ANTISIPASI OVER KAPASITAS LAPAS SUATU REFLEKSI ATAS KEBIJAKAN PENCEGAHAN PENYEBARAN COVID-19
}

\author{
${ }^{1}$ Samuel Arsheldon, ${ }^{2}$ Supriardoyo Simanjuntak, ${ }^{3}$ Kornelius Benuf \\ ${ }^{123}$ Fakultas Hukum Universitas Diponegoro \\ E-mail: samuelarsheldons@gmail.com
}

\begin{abstract}
The release policy of prisoners and children in the context of preventing and overcoming the spread of Covid-19, raises the pros and cons in the community. For those who are contra, this policy is considered inappropriate because it is considered to be able to add to unrest in the midst of a community that is suffering from a pandemic. This research discusses the problem of the prisoner-based prisoner release policy, and will provide a solution to the main problem facing Indonesia today, which is over-capacity prison. The research method used is normative juridical using secondary data, in the form of primary and secondary legal materials, obtained through literature study analyzed descriptively analytically. Based on the research results, it is known that if there are still at least two additional conditions, assimilation and integration are applied; Provision of assimilation and integration must involve supervisory judges and observers to be asked for their consideration and Risk Assessment. Furthermore, in the long term, in anticipating overcapacity in community institutions, it will immediately pass the Criminal Code Bill that has the concept of Criminal and Criminal Individualization, which is expected to be able to provide protection and welfare for the community and still pay attention to the interests of criminal offenders
\end{abstract}

Keywords:

Covid 19, prisoner release, over capacity Correctional Institution 


\begin{abstract}
Abstrak
Kebijakan pembebasan narapidana dan anak dalam rangka pencegahan dan penanggulangan penyebaran Covid-19, menimbulkan pro-kontra di tengah masyarakat. Bagi kalangan yang Kontra, kebijakan ini dinilai kurang tepat karena dianggap dapat menambah keresahan di tengahtengah masyarakat yang sedang terpuruk akibat pandemi. Penelitian ini membahas permasalahan tentang kebijakan pembebasan warga binaan pemasyarakatan, dan akan memberikan solusi terhadap permasalahan utama yang dihadapi Indonesia saat ini yaitu over kapasitas Lapas. Penelitian ini menggunakan metode yuridis normatif dengan menggunakan data sekunder, berupa bahan hukum primer dan sekunder, yang diperoleh melalui studi kepustakaan dianalisis secara deskriptif analitis. Berdasarkan hasil penelitian diketahui bahwa apabila tetap diberlakukan asimilasi dan integrasi setidaknya ada dua syarat tambahan yaitu; Pemberian asimilasi dan integrasi harus melibatkan hakim pengawas dan pengamat untuk dimintai pertimbangannya dan Risk Assessment (penakaran resiko). Selanjutnya untuk jangka panjang dalam mengantisipasi over kapasitas di lembaga pemasyarakat maka segera mengesahkan RUU KUHP yang mempunyai konsep Individualisasi Pidana dan Pemidanaan yang diharapkan mampu memberikan perlindungan dan kesejahteraan masyarakat serta tetap memperhatikan kepentingan pelaku tindak pidana.
\end{abstract}

\title{
Kata Kunci:
}

Covid 19, Pembebasan Napi, Over Kapasitas Lembaga Pemasyarakatan 


\section{Pendahuluan}

Problematika lembaga pemasyarakatan selaku lembaga untuk melaksanakan pembinaan bagi narapidana dan anak adalah selalu meningkatnya kelebihan kapasitas. Berdasarkan data yang dihimpun Bulan Juni 2020 Jumlah Penghuni Lapas Sebanyak 230.310 orang yang terdiri dari Tahanan sebesar 50.276 dan Narapidana 180.084. ${ }^{1}$ Hal ini menunjukkan bahwa lembaga pemasyarakatan di Indonesia sedang mengalami kelebihan kapasitas yang mencapai angka 74\% dalam skala nasional. Dari 33 Kanwil yang berada di Indonesia hanya ada 10 Kanwil yang tidak mengalami kelebihan kapasitas yaitu Kanwil. D.I Yogyakarta, Kanwil Gorontalo, Kanwil Maluku, Kanwil Maluku Utara, Kanwil Nusa Tenggara Timur, Kanwil Papua, Kanwil Papua Barat, Kanwil Sulawesi Barat, kanwil Sulawesi Tenggara dan Kanwil Sulawesi Utara.

Menyikapi kondisi tersebut pemerintah telah mengambil beberapa kebijakan seperti perbaikan bangunan atau rehabilitasi hingga pembuatan gedung baru untuk menambah daya tampung. Kondisi demikian merupakan permasalahan serius yang harus segera terselesaikan. Seperti yang disampaikan Woolf, "dalam mengelola lapas perlu memperhatikan faktor yang memperburuk kondisi dalam lapas, diantaranya: kepadatan penjara yang extreme; kelebihan penghuni; keadaan penjara yang buruk; kerusuhan diantara para tahanan dan lainnya."2 Kondisi tersebut diperburuk dengan terjadinya bencana non alam Corona Virus Disiase 2019 (Covid-19) yang telah menyebar dan menimbulkan jumlah korban dan kerugian harta beda yang semakin meluas dan masif di Indonesia. ${ }^{3}$

Pemerintah melalui Kementerian Hukum dan Ham dalam melakukan upaya pencegahan penyebaran Covid-19 di Lembaga Pemasyarakatan telah mengeluarkan "Permenkumham No.10 Tahun 2020 Tentang Syarat Pemberian Asimilasi dan Hak Integrasi Bagi Narapidana dan Anak dalam Rangka Pencegahan dan Penanggulangan Penyebaran Covid-19, dan Keputusan Menteri Hukum dan HAM No.19.PK.01.04 Tahun 2020 tentang Pengeluaran dan Pembebasan Narapidana Anak Melalui Asimilasi dan

1 Sistem Database Pemasyarakatan, <http://smslap.ditjenpas.go.id/public/grl /current /monthly>, Diakses Tanggal 21 Juni 2020.

2 Rissang Achmad Putra Perkasa, "Optimalisasi Pembinaan Narapidana dalam Upaya Mengurangi Overcapacity Lembaga Pemasyarakatan”, Jurnal Wajah Hukum, Volume 4, no. 1 ( April, 2020) Hlm. 110.

${ }^{3}$ Keputusan Presiden Republik Indonesia Nomor 12 Tahun 2020 Tentang Penetapan Bencana Nonalam Penyebaran Corona Virus Disease 2019 (Covid-19) Sebagai Bencana Nasional 
Integrasi dalam Rangka Pencegahan dan Penanggulangan Penyebaran Covid-19". Menurut Yunaedi selaku Direktur Pembinaan Narapidana dan Latihan Kerja Produksi Ditjen Pemasyarakatan Kemenkumham, dikeluarkannya kebijakan tersebut dapat menghemat anggaran negara untuk kebutuhan warga binaan pemasyarakatan (WBP) hingga mencapai angka Rp 341 Milyar. Penghitungan tersebut merupakan hasil penghitungan dari 270 hari, terhitung sejak April Hingga Desember 2020 yang dikalikan dengan biaya hidup tiap narapidana per hari, termasuk makan, kesehatan dan pembinaan sebesar 32.269.4

Kepadatan narapidana tersebut menimbulkan lembaga pemasyarakatan menjadi tempat yang sangat rentan terjadinya penularan virus Covid-19 secara masif dan cepat, jika salah satu dari penghuni lapas terkena virus tersebut. Mengingat para petugas pemasyarakatan tidak tinggal di dalam lapas, melainkan di luar kompleks lapas yang sudah barang tentu berinteraksi dengan masyarakat sekitarnya. Ditambah lagi pemerintah telah mengeluarkan kebijakan untuk menerapkan physical distancing, atas dasar itu maka sangat urgent untuk mengambil tindakan untuk mencegah dan menghalau penyebaran Covid-19 di dalam lembaga pemasyarakatan. Penelitian yang membahas kajian yang sama dengan penelitian ini sudah pernah dikaji oleh Safaruddin Harefa pada tahun 2018 dalam tulisannya yang berjudul Kebijakan Kriminal Dalam Menanggulangi Kelebihan Kapasitas Lembaga Pemasyarakatan 5 .

Penelitian tersebut menguraikan faktor-faktor yang mempengaruhi kepadatan lapas, kebijakan lapas Wirogunan untuk menanggulangi kelebihan kapasitas yang dilengkapi dengan formulasi pidana dan pemidanaan untuk mengurangi kelebihan kapasitas di Lapas. penelitian ini tidak menguraikan secara rinci mengenai kajian teori tujuan dan pedoman pemidanaan dalam mengurangi over kapasitas yang terlihat dari solusi yang ditawarkan dalam kesimpulan yaitu melakukan revisi KUHP dan merubah pandangan hakim yang cenderung menjatuhkan pidana Penjara dan menambah Lapas di Indonesia. Penelitian ini berbeda dengan penelitian sebelumnya yang membahas permasalahan yang sama yaitu menanggulangi kepadatan Lapas, penelitian ini berfokus pada Strategi

4 Jpnn.com, "39 RIbu Narapidana Dibebaskan, Negara Hemat Anggaran Rp. 341 Miliar, < < <ttps://www.jpnn.com/news/39-ribu-narapidana-dibebaskan-negara-hematanggaran-rp-341-miliar>, Diakses 15 Mei 2020.

${ }^{5}$ Safaruddin Harefa, "Kebijakan Kriminal Dalam Menanggulangi Kelebihan Kapasitas Lembaga Pemasyarakatan”, Jurnal Yuridis, Volume 5, No. 2, (November 2020), Hlm. 294. 
Antisipasi Over Kapasitas di Lembaga Permasyarakatan sebagai Suatu Refleksi atas Kebijakan Pencegahan Penyebaran Covid-19, dalam Pembaharuan Hukum Pidana.

Berbagai kebijakan telah dikeluarkan pemerintah guna mencegah penyebaran Covid-19 di Lembaga Permasyarakatan, Namun kebijakan ini masih perlu dievaluasi dalam pelaksanaanya. Mengingat Narapidana yang dilepaskan melalui asimilasi dan integrasi hingga hari ini (13/05/2020) setidaknya sudah ada 106 narapidana yang kembali berulah dengan persebaran paling banyak di Jawa Tengah, Jawa Barat dan Sumatera Utara. ${ }^{6}$ Untuk itu, penting rasanya untuk membahas mengenai Strategi Antisipasi Over Kapasitas Lapas Refleksi atas Kebijakan Pencegahan Penyebaran Covid-19. Dengan harapan mampu mencegah terjadinya Over Kapasitas di Lembaga Pemasyarakatan di masa yang akan datang. Dalam penelitian ini, yang menjadi permasalahan adalah Bagaimana Kebijakan Pencegahan Penyebaran Covid-19 di Lembaga Permasyarakatan saat ini? Bagaimana Strategi Antisipasi Over Kapasitas di Lembaga Permasyarakatan sebagai Suatu Refleksi atas Kebijakan Pencegahan Penyebaran Covid-19, dalam Pembaharuan Hukum Pidana?

\section{Metode Penelitian}

Metode penelitian yang digunakan adalah penelitian yuridis normatif yaitu penelitian hukum yang mendasarkan analisisnya pada peraturan perundang-undangan yang berlaku dan relevan dengan permasalahan hukum yang diteliti. ${ }^{7}$ Adapun penelitian ini akan menganalisa dan mengkaji bahan serta isu hukum yang berkaitan dengan strategi antisipasi over kapasitas Lapas dalam kaitanya dengan pencegahan penyebaran covid-19. Pendekatan yang digunakan dalam penelitian ini adalah pendekatan "perundang-undangan (statute approach) disertai dengan pendekatan konseptual (conceptual approach)", dilakukan dengan menelaah undangundang terkait strategi antisipasi over kapasitas Lapas dalam kaitanya dengan pencegahan penyebaran Covid-19. Data yang digunakan yaitu data sekunder yang terdiri atas bahan hukum primer dan bahan hukum

6 Cnnindonesia.com. "106 Napi Asimilasi Kembali Berulah, Mencuri Hingga Pencabulan",<https://www.cnnindonesia.com/nasional/20200512150324-12-502544/106napi - asimilasi-kembali -berulah-mencuri-hingga-pencabulan> Diakses 15 Mei 2020.

7 Kornelius Benuf dan Muhamad Azhar, "Metodologi Penelitian Hukum Sebagai Instrumen Instrumen Mengurangi Permasalahan Hukum Kontemporer", Jurnal Gema Keadilan, Volume 7, Edisi 1 (Juni 2020), Hlm. 24. 
sekunder. Bahan hukum primer berupa Peraturan Perundang-Undangan yang berhubungan dengan penelitian ini sedangkan bahan hukum sekunder yang digunakan adalah semua literatur yang terkait dengan isu hukum yang dibahas baik buku-buku teks, jurnal hukum, dan lainnya. Kemudian Teknik pengumpulan data yang digunakan dalam penelitian ini adalah studi kepustakaan yang mengkaji data-data sekunder. Analisis data dilakukan secara kualitatif yang dilengkapi dengan hasil wawancara yang ditujukan untuk menarik kesimpulan mengenai strategi antisipasi over kapasitas Lapas dalam kaitanya dengan pencegahan penyebaran Covid-19.

\section{Hasil dan Pembahasan}

\section{Kebijakan Pemerintah dalam Pencegahan Penyebaran Covid-19 di Lembaga Permasyarakatan}

Pemerintah melalui Kementerian Hukum dan HAM (KEMENKUMHAM) Pada Tanggal 30 Maret 2020, Menetapkan "Keputusan Menteri Hukum dan Hak Asasi Manusia Republik Indonesia Nomor M.Hh-19.Pk.01. 04.04 Tahun 2020 Tentang Pengeluaran dan Pembebasan Narapidana dan Anak Melalui Asimilasi dan Integrasi dalam Rangka Pencegahan dan Penanggulangan Penyebaran Covid-19", yang selanjutnya disebut "Kebijakan Pencegahan Penyebaran Covid-19 di Lapas". Keputusan menteri ini merupakan kebijakan pemerintah yang diambil dalam rangka "menyelamatkan Tahanan dan Warga Binaan Pemasyarakatan yang berada di Lembaga Pemasyarakatan, Lembaga Pembinaan Khusus Anak, dan Rumah Tahanan Negara". Pertimbangan pemerintah mengeluarkan kebijakan ini utamanya adalah karena kondisi Lapas, Lembaga Khusus Anak, dan Rumah Tahanan Negara, merupakan sebuah institusi tertutup yang memiliki tingkat hunian tinggi, sehingga sangat rentan terhadap penyebaran dan penularan Covid19.

Kebijakan Pencegahan Penyebaran Covid-19 di Lapas, ditujukan untuk Narapidana dan Anak, pelaku tindak pidana umum. Artinya kebijakan ini bukan untuk Narapidana pelaku tindak pidana khusus, sehingga tindak pidana korupsi, terorisme, narkoba, dan tindak pidana khusus lainnya tidak bisa dikeluarkan dengan menggunakan kebijakan ini. Pada intinya, kebijakan pencegahan penyebaran Covid-19 di Lapas akan mengeluarkan dan membebaskan Narapidana dan Anak melalui program asimilasi dan integrasi sebagai upaya pencegahan dan penyelamatan/ antisasi Narapidana dan Anak dari Penyebaran Covid-19 yang berada di Lembaga 
Pemasyarakatan, Lembaga Pembinaan Khusus Anak, dan Rumah Tahanan Negara sebagaimana di atur dalam bagian kesatu, kebijakan a quo.

Pengeluaran dan pembebasan Narapidana dan Anak dilakukan melalui 2 (dua) cara. Cara yang pertama yaitu melalui asimilasi, ketentuan seorang narapidana mendapatkan asimilasi yaitu " $2 / 3$ (dua per tiga) masa pidananya jatuh sampai dengan tanggal 31 Desember 2020. Bagi Anak yaitu $1 / 2$ (setengah) masa pidananya jatuh sampai dengan tanggal 31 Desember 2020. Narapidana dan anak yang tidak terkait dengan PP 99 Tahun 2012, yang tidak sedang menjalani subsidaer dan bukan warga negara asing, asimilasi dilaksanakan di rumah, Surat keputusan asimilasi diterbitkan oleh Kepala Lapas, Kepala LPKA, dan Kepala Rutan".

Cara yang kedua yaitu melalui integrasi, adapun ketentuan Narapidana untuk mendapatkan integrasi yaitu "telah menjalani 2/3 masa pidana, bagi Anak telah menjalani 1/2 masa pidana, Narapidana dan Anak yang tidak terkait dengan PP nomor 99 tahun 2012, yang tidak sedang menjalani subsidaer dan bukan warga negara asing, Usulan dilakukan melalui system database pemasyarakatan, Surat keputusan integrasi diterbitkan oleh Direktur Jenderal Pemasyarakatan". Melalui dua cara inilah, sebagai mana yang telah diatur dalam Kebijakan Pencegahan Penyebaran Covid-19 di Lapas, seorang Narapidana dan anak bisa dikeluarkan dan dibebaskan, namun tatap mendapatkan Pembimbingan dan pengawasan asimilasi dan integrasi dilaksanakan oleh Balai Pemasyarakatan. Diatur pula bahwa adanya "laporan pembimbingan dan pengawasan dilakukan secara daring". Kepala Bagian Humas Publikasi Ditjen Pemasyarakatan Rika Aprianti menjelaskan bahwa "asimilasi dan integrasi Narapidana dan anak tanggal 2 Mei 2020 dengan total 39.273 Narapidana, dengan rincian 37.014 warga binaan dibebaskan melalui program asimilasi sementara melalui program integrasi Narapidana yang bebas sebanyak 2.259.8

\section{Dampak Pembebasan Narapidana dan Anak bagi Masyarakat}

Pembebasan Narapidana melalui program asimilasi dan integrasi sebagai kebijakan pemerintah mencegah penyebaran Covid-19 di Lapas, menimbulkan keresahan di masyarakat. Hal ini dikarenakan masih terdapat Narapidana yang dibebaskan kembali melakukan tindak

8 Kumparan.com, "39 Ribu Napi Dibebaskan karena Asimilasi Corona, 90 Orang Berulah Lagi”,<https://kumparan.com/kumparannews/39-ribu-napi-dibebaskan-karenaasimilasi-coro na-95-orang-berulah-lagi-1tOSeawgtg6/full>, Diakses 15 Mei 2020. 
pidana. Hingga pada tanggal 12 Mei 2020, terdapat 106 narapidana melakukan tindak pidana lagi dan harus ditangkap akibat kembali berulah melakukan Tindakan kriminal. ${ }^{9}$ Contoh lain Napi yang kembali melakukan tindak pidana setelah dibebaskan yaitu;

"Dua orang residivis bernama M Bahri (25) warga Gundih, Surabaya dan Yayan (23) warga Margorukun, Surabaya, kembali diamankan polisi. Mereka ditangkap karena terlibat dalam kasus penjambretan yang terjadi di Jalan Darmo Surabaya, Kamis (9/4/2020)".10 Memang tidak semua Napi yang dibebaskan kembali melakukan tindak pidana. Namun dua contoh di atas sudah bisa menggambarkan dampak yang disebabkan karena adanya kebijakan pembebasan Narapidana dan Anak yang telah diterapkan di Indonesia.

Kepala Badan Reserse Kriminal (Kabareskrim) Polri menyebutkan, "dari 39.273 Narapidana asimilasi yang dibebaskan, terdapat 106 orang kembali berulah atau sekitar 0,27\%.11 Statistik kriminal yang disampaikan oleh Kabareskrim merupakan data yang tercatat dan terlaporkan. Jika kita mengacu terhadap statistik kriminal, bahwa hasil pencatatan yang dilakukan oleh aparat penegak hukum (khususnya polisi) didominasi atas laporan korban dan anggota masyarakat ("berdasarkan berbagai studi sekitar $80-90 \%$ pencatatan tersebut berasal dari laporan masyarakat").12 Namun apa yang disampaikan oleh Kabereskrim tersebut hanyalah kasus yang terlapor dan tercatat di kepolisian. Masih memungkinkan adanya tindak pidana yang dilakukan Napi yang dibebaskan namun tidak dilaporkan dan tidak dicatat. Hal ini sejalan dengan teori Statistik Kriminal" yang apabila digambarkan akan terlihat sebagai berikut:

9 Cnnindonesia.com, 106 Napi Asimilasi Kembali Berulah, Mencuri Hingga Pencabulan, <https://www.cnnindonesia.com/nasional/20200512150324-12-502544/ 106-napi-asimil asi-kembali-berulah-mencuri-hingga-pencabulan,> Diakses 15 Mei 2020.

10 Kompas.com "Sederet Kasus Napi yang Dibebaskan Kembali Berulah dan Ditangkap Polisi", <https://regional.kompas.com/read/2020/04/12/ 06100011 /sederetkasus-napi-yang-dibebaskan-kembali-berulah-dan-ditangkap-polisi> Diakses 18 Mei 2020

11 Cnnindonesia.com, 106 Napi Asimilasi Kembali Berulah, Mencuri Hingga Pencabulan, https://www.cnnindonesia.com/nasional/20200512150324-12-502544 /106napi-asimilasi-kembali-berulah-mencuri-hingga-pencabulan, Diakses 15 Mei 2020.

12 I.S. Susanto, Kriminologi, (Yogyakarta: Genta Publishing, 2011), Hlm. 45 
Skema 1: Statistik Kriminal

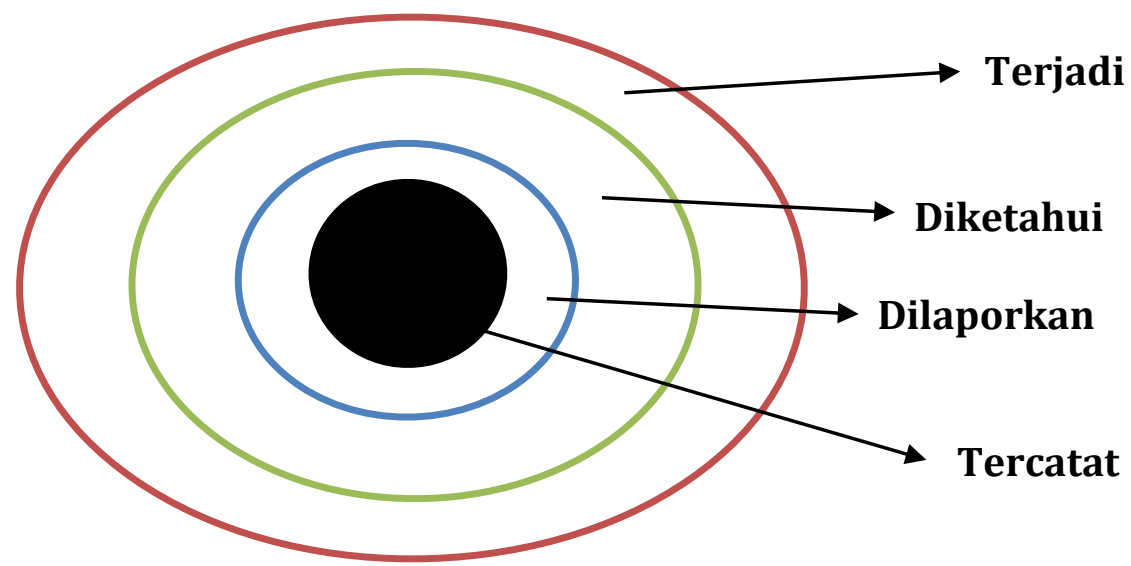

Berdasarkan skema di atas, maka sangat jelas bahwa tindak pidana yang tercatat bukan gambaran yang representatif tentang kriminalitas tetapi tentang gambaran mengenai aktifitas penegak hukum. Sejalan dengan hal tersebut, tindak pidana yang dilakukan oleh Narapidana yang dibebaskan berdasarkan program asimilasi dan integrasi tidak dapat dipastikan bahwa Narapidana yang melakukan tindak pidana setelah terbebas dari Lembaga Permasyarakatan hanya 106 orang, namun sangat dimungkinkan masih banyak Narapidana yang melakukan tindak pidana tanpa diketahui oleh aparat penegak hukum maupun masyarakat.

Pembebasan Narapidana melalui program asimilasi dan integrasi menimbulkan kerasahan dimasyarakat karena telah terjadi tindak pidana yang dilakukan narapidana tindak pidana pencurian hingga tindak pidana pelecehan seksual. Menindaklanjuti realitas dilapangan Ketua Komisi III DPR RI Herman Herry menyatakan "bahwa kriteria narapidana yang akan dikeluarkan lewat kebijakan percepatan asimilasi harus diawasi dengan ketak" dan dilakukan secara serius dengan tujuan untuk meminimalisir kemungkinan narapidana asimilasi melakukan tindak pidana kembali dimasyarakat. ${ }^{13}$

Guna memberikan rasa aman terhadap masyarakat jika pemerintah (dalam hal ini Kemenkumham) menerapkan kebijakan pembebasan Narapidana dan Anak melalui program asimilasi dan integrasi, maka

13 Cnnindonesia.com 106 Napi Asimilasi Kembali Berulah, Mencuri Hingga Pencabulan, <https://www.cnnindonesia.com/nasional/20200512150324-12-502544/106napi-asimilasi -kembali-berulah-mencuri-hingga-pencabulan,> Diakses 15 Mei 2020. 
harus ditempuh dengan cara memperketat syarat, sehingga diharapkan Narapidana yang keluar dan berbaur di masyarakat merupakan orang yang telah mengakui dan tidak mengulang kembali perbuatanya. Syarat tambahan yang harus diterapkan bagi Narapidana apabila dilain kesempatan ingin menerapkan program asimilasi dan integrasi dalam rangka pencegahan penyebaran pandemi seperti Covid-19, setidaknya ada dua syarat tambahan yaitu; Pemberian asimilasi dan integrasi harus melibatkan hakim pengawas dan pengamat untuk dimintai pertimbangannya dan Risk Assessment (penakaran resiko).

Syarat tambahan pertama yaitu pemberian asimilasi dan integrasi harus melibatkan hakim pengawas dan pengamat untuk dimintai pertimbangannya. Hal ini sejalan dengan Pasal 280 ayat $1 \mathrm{KUHAP}^{14}$ yang menyatakan bahwa "Hakim pengawas dan pengamat mengadakan pengawasan guna memperoleh kepastian putusan pengadilan dilaksanakan". Selanjutnya ayat 2 menyatakan bahwa "Hakim pengawas dan pengamat mengadakan pengamatan untuk bahan penelitian demi ketetapan yang bermanfaat bagi pemidanaan, yang diperoleh dari perilaku narapidana atau pembinaan lembaga pemasyarakatan serta pengaruh timbal-balik terhadap narapidana selama menjalani pidananya". Ayat 3 yang pada intinya menyatakan bahwa hakim pengawas dan pengamat tetap melakukan pengamatan setelah terpidana selesai menjalani pidananya. Hal ini juga berdasarkan "Surat Edaran Mahkamah Agung No. 7 Tahun 1985, tentang petunjuk Pelaksanaan Tugas Hakim Pengawas dan Pengamat", yang menentukan tugas teknis hakim pengawas dan pengamat dalam melakukan pengawasan dan pengamatan dengan menghubungi kepala lembaga pemasyarakatan dan ketua pembina pemasyarakatan, dalam rangka saling tukar menukar saran pendapat dalam pemecahan suatu masalah, yang dalam pemecahan masalah mengenai pencegahan penyebaran Covid-19 di lembaga pemasyarakatan ${ }^{15}$. Syarat tambahan ini dibuat agar tidak ada persepsi masyarakat bahwa "Keputusan Menteri dalam hal ini Menteri Hukum dan HAM bisa merubah putusan pengadilan", dan guna memberikan keadilan, kepastian, dan kemanfaatan hukum bagi masyarakat.

14 Pasal 280 Undang-Undang Nomor 8 Tahun 1981 Tentang Kitab Undang Undang Hukum Acara Pidana

${ }^{15}$ Surat Edaran Mahkamah Agung No. 7 Tahun 1985, tentang petunjuk Pelaksanaan Tugas Hakim Pengawas dan Pengamat 
Syarat tambahan yang kedua yaitu Risk Assessment Menurut ahli psikologi forensik, Reza Indragiri, para warga bianaan yang dikeluarkan dari lembaga pemasyarakatan perlu melalui tahap penakaran risiko (risk assessment) sebelum dikeluarkan dari lembaga pemasyarakatan. Risk assessment adalah sebuah cara yang harus dipraktikkan dalam rangka menjawab kegelisahan atau pertanyaan masyarakat tentang rasa aman mereka, hal ini dilakukan agar mengurangi ancaman bahaya yang kemungkinan dilakukan oleh seorang warga binaan, ketika sudah dibebaskan. ${ }^{16}$

Kedua persyaratan yang dikemukakan di atas, dijiwai oleh ruh hukum progresif, yang dikemukakan oleh Prof. Satjipto Rahardjo, beliau mengatakan bahwa "hukum itu untuk manusia, bukan manusia untuk hukum"17, sehingga apabila dibawa dalam konteks penambahan dua syarat pembebasan Narapidana dan anak, yaitu; Pemberian asimilasi dan integrasi harus melibatkan hakim pengawas dan pengamat untuk dimintai pertimbangannya dan Risk Assessment (penakaran resiko), hal ini bertujuan agar apabila Narapidana dan anak tersebut kembali ke masyarakat, mereka tidak mengulangi kejahatan yang pernah mereka lakukan, tidak melakukan kejahatan lagi, dan masyarakat secara umum tidak merasa ketakutan. Sehingga pada akhirnya, kebijakan tersebut akan bermanfaat pada kehidupan masyarakat secara umum.

\section{Strategi Antisipasi Over Kapasitas di Lembaga Permasyarakatan sebagai Suatu Refleksi atas Kebijakan Pencegahan Penyebaran Covid-19, dalam Pembaharuan Hukum Pidana}

Pencegahan Over Kapasitas di Lembaga Pemasyarakatan, dalam pembaharuan hukum pidana perlu dilakukan guna mengantisipasi pelonjakan Narapidana yang terus menerus meningkat. Pelonjakan Narapidana disebabkan tindak pidana yang diancam pidana penjara paling banyak dalam KUHP. Bila mengacu terhadap KUHP dalam Pasal 10, dijelaskan bahwa pidana pokok yang dapat dijatuhkan adalah pidana mati, pidana seumur hidup, pidana penjara, pidana denda, pidana kurungan dan ditambah lagi pidana tutupan, dalam pelaksanaan pemidanaan

16 TV One, "Napi Dibebaskan, Ahli Psikologi Forensik: Lapas Menjadi Tempat Aman untuk Isolasi Covid-19", https://www.youtube.com/watch?v=zi5zdcuWp0k, Diakses Tanggal 3 Mei 2020

17 Satjipto Rahardjo, Membedah hukum progresif, (Jakarta: Penerbit Buku Kompas, 2006) Hlm. 34. 
hakim cenderung memutus perkara dengan menjatuhkan pidana penjara, hal ini dikarenakan sistem pemidanaan yang kaku dalam KUHP saat ini. Akan tetapi, dalam Rancangan Undang-Undang Hukum Pidana telah mengakomodir langkah-langkah yang diharapkan mampu mencegah terjadinya over kapasitas di Lembaga Permasyarakatan di antaranya:

\section{Reorientasi Tujuan Pemidanaan}

Pembaharuan Hukum Pidana sudah dimulai semenjak lahirnya UUD NRI Tahun 1945), tidak dapat dipisahkan dari tujuan nasional yang termaktub dalam pembukaan alinea ke-4 UUD NRI Tahun 1945, yaitu "untuk melindungi segenap bangsa Indonesia dan untuk memajukan kesejahteraan umum berdasarkan Pancasila".18 Tujuan nasional identik dengan istilah "social defence/perlindungan masyarakat dan social Welfare/kesejahteraan masyarakat. ${ }^{19}$ Berdasarkan kebijakan hukum pidana maka "tujuan pemidanaan harus diarahkan kepada perlindungan masyarakat dari kesejahteraan serta keseimbangan dan keselerasan hidup dalam masyarakat dengan memperhatikan kepentingan masyarakat /negara, korban dan pelaku" ${ }^{20}$

Pemberian sanksi pidana merupakan sebuah sarana untuk mencapai tujuan pemidanaan yang terfokus untuk memberikan keseimbangan antara "perlindungan masyarakat dan perlindungan /pembinaan individu pelaku tindak pidana". Barda Nawawi Arief berpendapat, pada pokoknya pemidanaan mengandung dua aspek tujuan utama, diantaranya "(a) Aspek perlindungan masyarakat terhadap tindak pidana meliputi; pencegahan kejahatan; pengayoman (pengamanan) masyarakat; dan pemulihan keseimbangan masyarakat (penyelesaian konflik (conflict oplossing) dan mendatangkan rasa damai (vrede-making)); (b) Aspek perlindungan/ pembinaan individu pelaku tindak pidana (aspek individualisasi pidana) meliputi: (1) rehabilitasi, readuksasi, resosialisasi (memasyarakatkan) terpidana agar tidak melakukan perbuatan-perbuatan yang merusak/ merugikan diri sendiri maupun orang lain/ masyarakat dan agar berbudi pekerti (berakhlak) Pancasila, (2) membebaskan rasa bersalah, dan (3)

18 Pembukaan Undang-Undang Dasar Negara Kesatuan Republik Indonesia Tahun 1945

19 Barda Nawawi Arief, Tujuan dan Pedoman Pemidanaan (Perspektif Pembaharuan dan Perbandingan Hukum Pidana), (Semarang:Pustaka Magister, 2017), Hlm. 32

20 Pusat Perencanaan Pembangunan Hukum Nasional, "Perencanaan Pembangunan Hukum Nasional Politik Hukum Pidana dan Sistem Pemidanaan, Jakarta: 2010, Hlm. 21 
melindungi si pelaku dari pengenaan sanksi atau pembalasan yang sewenang-wenang tidak manusiawi (pidana tidak dimaksudkan untuk menderitakan dan merendahkan martabat manusia)". ${ }^{21}$

Sanksi pidana yang dijatuhkan dan dikenakan untuk pelaku tindak pidana sejatinya harus menimbulkan keseimbangan antara masyarakat dan pelaku tindak pidana. Dalam hukum pidana Indonesia tujuan pemidanaan telah mengalami perubahan dan perkembangan secara kompleks sehingga yang diharapkan mampu memberikan sumbangsih dalam proses pemidanaan. Pada umunya, teori pemidanaan dapat dibagi menjadi tiga, yaitu teori absolut atau teori pembalasan (retributive /vergeldingstheorieen), teori relatif atau teori tujuan (utilitarian/doeltheorieen), dan teori gabungan (integratif).

Teori absolut atau teori pembalasan (retributive/ vergeldingstheorieen), Penjatuhan pidana terhadap pelaku tindak pidana menurut teori ini disebabkan pelaku tindak pidana telah melakukan perbuatan yang merugikan masyarakat. Dalam teori ini pidana atau pencelaan dilakukan secara murni tanpa memiliki tujuan untuk mendidik, atau memasyarakatkan kembali si pelanggar, melainkan hanya ditujukan untuk melakukan pembalasan setimpal dengan perbuatan yang dilakukan pelaku. Mabbott memandang bahwa "pemidanaan merupakan akibat wajar yang disebabkan bukan dari hukum, tetapi dari pelanggaran hukum." 22 Artinya jika ada seseorang telah bersalah melanggar hukum yang berlaku, jahat tidak jahat maka orang tersebut harus dipidana sesuai dengan perbuatannya.

Teori relative atau teori tujuan (utilitarian/ doeltheorieen), Pada dasarnya Pemidanaan tidak bertujuan memberikan pembalasan terhadap pelaku tindak pidana melainkan hanya sebagai langkah untuk melindungi masyarakat. Menurut teori ini dasar pembenaran adalah terletak pada tujuannya. Disatu sisi pemidanaan dimaksudkan untuk memperbaiki sikap dan tingkah laku pelaku tindak pidana dan disisi lain di dimaksudkan untuk mencegah pelaku tindak pidana atau orang lain melakukan perbuatan yang sama. ${ }^{23}$ Pidana dijatuhkan bukan "quia peccatum est" (karena orang membuat kejahatan) melainkan "ne peccetur"

${ }^{21}$ Barda Nawawi Arief, Op. Cit, Hlm. 37-38

22 Pusat Perencanaan Pembangunan Hukum Nasional, Op.Cit. Hlm. 22

23 Marcus Priyo Gunarto, "Sikap Memidana yang beriorientasi Pada Tujuan Pemidanaan”, Mimbar Hukum, Volume 21 no. 1, ( Februari 2009), Hlm. 101. 
(supaya orang jangan melakukan kejahatan).24 Sehingga pandangan ini dapat dikatakan beriorientasi kedepan dan bersifat pencegahan.

Teori gabungan (Integratif) Van Bammelen berpendapat pemidanaan bertujuan untuk membalaskan kesalahan pelaku tindak pidana dan disisi lain untuk mengamankan masyarakat. Dengan demikian, pidana dan tindakan keduanya bertujuan mempersiapkan untuk mengembalikan terpidana kedalam masyarakat. ${ }^{25}$ Sehingga dapat dikatakan bahwa teori gabungan ini merupakan perpaduan dari teori-teori sebelumnya yang membentuk suatu teori yang lebih sempurna.

Munculnya teori gabungan (integratif) merupakan penyempurnaan dari teori sebelumnya dengan menekankan tujuan pemidanaan yang seimbang. ${ }^{26}$ Muladi berpendapat bahwa "di Indonesia, tujuan pemidanaan yang tepat diterapkan adalah teori integratif. Alasanya, bahwa pada saat ini masalah pemidanaan menjadi permasalahan yang sangat kompleks, disebabkan karena perhatian lebih banyak terhadap hak asasi manusia serta keinginan untuk menjadikan pidana bersifat operasional dan fungsional. Sehingga pilihan terhadap teori integratif itu menghendaki adanya pendekatan multidimensi terhadap dampak pemidanaan". ${ }^{27}$

Sistem pemasyarakatan di Indonesia sudah menerapkan teori integratif yang telah diakomodir dalam undang-undang tentang pemasyarakatan, Unsur teori Integratif terlihat adanya langkah untuk mengekang para pelaku tindak pidana dalam waktu tertentu sebagai langkah pembalasan atas perbuatan yang dilakukanya. Pengekangan yang dimaksud dilakukan pada "Lembaga Permasyarakatan (Lapas) dan Rumah Tahanan (Rutan) dengan sistem maximum security". Unsur teori relatif terlihat dalam pelaksanaan tahapan-tahapan pembinaan yang dilaksanakan pada sistem permasyarakatan. Dilihat dari uraian diatas, maka pemberlakukan teori integratif dalam lembaga permasyarakatan memang tepat untuk diterapkan.

\footnotetext{
${ }^{24}$ Muladi dan Barda Nawawi Arief, Teori-Teori dan Kebijakan Pidana, (Bandung: PT. Alumni Bandung, 2010), Hlm. 16.

${ }^{25}$ Andi Hamzah, Sistem Pidana dan Pemidanaan di Indonesia, (Jakarta: Pradnya Paramita, 1993), Hlm. 26.

${ }^{26}$ Ismail Rumadan, "Problem Lembaga Pemasyarakatan di Indonesia dan Reorientasi Tujuan Pemidanaan", Jurnal Hukum dan Peradilan, Volume 2, no. 2, (Juli 2013), Hlm. 268.

27 Muladi, Lembaga Pidana Bersyarat, (Bandung: PT Alumni, 2004), Hlm 49-51. Dalam Ismail Rumadan, "Problem Lembaga Pemasyarakatan di Indonesia dan Reorientasi Tujuan Pemidanaan", Jurnal Hukum dan Peradilan, Volume 2 no. 2, (Juli 2013), Hlm. 269.
} 
Penerapan Teori Integratif dalam Lembaga Permasyarakatan belum mampu secara maksimal dalam mengurangi overkapasitas dalam Lapas dan Rutan karena jumlah pelaku tindak pidana dan tahanan semakin lama semakin banyak. Banyaknya tahanan tersebut dikarenakan KUHP selaku aturan yang mengatur mengenai perbuatan yang dilarang tidak mengatur secara jelas dan eksplisit mengenai tujuan pemidanaan, sehingga para aparat penegak hukum selalu cenderung melakukan penuntutan dan hakim cenderung menjatuhkan pidana penjara terhadap pelaku tindak pidana, karena teori dan pemikiran yang dianut atau diyakini oleh aparat penegak hukum tidak satu pemikiran.

Pada prinsipnya Lapas selain sebagai tempat pelaksanan pidana penjara juga berfungsi sebagai lembaga pendidikan dan pembangunan, sebagai lembaga pendidikan artinya Lapas mendidik Napi agar menjadi manusia yang berkualitas yaitu beriman kepada Tuhan dan berbudi baik, dan sebagai lembaga pembangunan artinya menjadikan manusia yang produktif baik di dalam Lapas atau ketika sudah di masyarakat demi mensukseskan pembangunan nasional ${ }^{28}$. Sebagai alternatif upaya untuk mengurangi over kapasitas Lapas yaitu "program pembinaan narapidana Pengurangan masa menjalani pidana dengan melakukan suatu pekerjaan baik merupakan ketentuan pelaksana pidana penjara melalui program pembinaan narapidana di dalam maupun diluar lembaga pemasyarakatan yang di sediakan pemerintah atau lembaga sosial"29. Alternatif ini dalam RUU KUHP disebut Pidana Kerja Sosial.

Menjawab permasalahan yang diuraikan di atas, maka adanya RUU KUHP diharapkan mampu menyamakan persepsi aparat penegak hukum mengenai penjatuhan pidana terhadap pelaku tindak pidana. Sebagaimana dalam konsep Rancangan Buku I Pasal 51 KUHP (perSeptember 2019), pemidanaan bertujuan untuk: "a) mencegah dilakukanya tindak pidana dengan menegakkan norma hukum demi perlindungan dan pengayoman masyarakat; b) memasyarakatkan terpidana dengan mengadakan pembinaan dan pembimbingan agar menjadi orang yang baik dan berguna; c) menyelesaikan konflik yang ditimbulkan

28 Angkasa, "Over Capacity Narapidana di Lembaga Pemasyarakatan, Faktor Penyebab, Implikasi Negatif, serta Solusi dalam Upaya Optimalisasi Pembinaan Narapidana", Jurnal Dinamika Hukum, Volume 10, no. 3, ( September 2010), Hlm. 213.

${ }^{29}$ Galih Puji Mulyono dan Barda Nawawi Arief, "Upaya Mengurangi Kepadatan Narapidana dalam Lembaga Pemasyarakatan di Indonesia" , Jurnal Law Reform, Volume 12, no. 1, (Maret 2016), Hlm. 14. 
akibat tindak pidana, memulihkan keseimbangan, serta mendatangkan rasa aman dan damai dalam masyarakat; dan d) menumbukan rasa penyesalan dan membebaskan rasa bersalah pada terpidana".30

Sehubungan Tujuan pemidanaan yang telah dirumuskan dalam konsep RUU KUHP, Sudarto berpendapat "bahwa dalam tujuan pertama tersimpul pandangan perlindungan masyarakat (social defence) dan bersifat general prevention, sedang dalam tujuan kedua dikandung maksud rehabilitasi dan resosialisasi terpidana (special prevention)". Kemudian dalam "Tujuan ketiga sesuai dengan pandangan hukum adat mengenai adat reactive, untuk mengembalikan keseimbangan kosmos karena kejahatan dianggap telah menggoncangkan keseimbangan (evenwichtverstoring), sedangkan tujuan yang keempat bersifat spiritual yang sesuai dengan sila pertama Pancasila" 31 .

Mencermati tujuan pemidanaan yang telah diatur dalam RUU KUHP, dapat kita melihat bahwa penjatuhan pidana terhadap pelaku tindak pidana tidak terfokus kepada pembalasan atau penebusan dosa sebagai tujuan utama teori retributif (teori absolut) dan tujuan penjatuhan pidana tidak terfokus sebagai sarana untuk melakukan pencegahan terjadinya kejahatan untuk memberikan perlindungan masyarakat teori utilitarian (teori relatif). Namun, tujuan pemidanaan yang dirumuskan dalam RUU KUHP merupakan kombinasi dari teori absolut dan teori relatif, sehingga muncul teori gabungan (teori integratif) yang mengkombinasikan dua tujuan pemidanaan yaitu pembalasan terhadap tindak pidana yang dilakukan oleh si pelaku dan memberikan perlindungan terhadap masyarakat. sehingga sangat jelas bahwa dalam teori integratif telah terkandung maksud pembalasan dan tujuan yang hendak dicapai. ${ }^{32}$

Oleh karena itu, maka diharapkan dengan berlakunya RUU KUHP dimasa yang akan datang maka aparat penegak hukum harus beriorintasi terhadap pelaku dan korban sehingga penjatuhan pidana selalu memperhatikan kedua belah pihak yang selalu mengharapkan terciptanya keadilan.

\footnotetext{
30 Pasal 51 Rancangan Undang-Undang Hukum Pidana Konsep September 2019

31 Naskah Akademik Rancangan Undang-Undang Hukum Pidana, Hlm. 42

32 Ismail Rumadan, Hlm. 269
} 


\section{Konsep Individualisasi Pidana}

RUU KUHP selain memuat reorientasi tujuan pemidanaan juga memuat konsep Individualisasi Pidana yang berasal dari aliran pemidanaan modern. Menurut aliran ini, dalam mencari kejahatan seseorang tidak dapat dilihat secara abstrak dari sudut yuridis semata namun harus dilihat dan ditelusuri secara konkrit bahwa dalam kenyataanya perbuatan seseorang itu dipengaruhi oleh faktor biologis, watak pribadi, dan perlindungan masyarakat. ${ }^{33}$ Hal ini menunjukkan bahwa aliran modern memiliki tujuan yang bersifat manusiawi untuk melindungi kepentingan si terpidana, sekaligus melindungi masyarakat yang di dalamnya termasuk korban tindak pidana yang menekankan agar pemidanaan harus memperhatikan tujuan dari pada pidana itu sendiri. Hal ini merupakan salah satu jawaban atas permasalahan over kapasitas Lapas di Indonesia yang dikarenakan pidana penjara merupakan sanksi pidana paling banyak dan paling sering dijatuhkan di Indonesia ${ }^{34}$.

Adanya konsep individualisasi pidana yang nantinya akan dibawa oleh RUU KUHP memilik beberapa karakteristik, antara lain seperti:35 "Pertanggungjawaban (pidana) bersifat pribadi/perorangan (asas personal); Pidana hanya diberikan kepada orang yang bersalah (asas culpabilitas: tiada pidana tanpa kesalahan); dan Pidana harus disesuaikan dengan karakteristik dan kondisi si pelaku, ini berarti harus ada kelonggaran/fleksibilitas bagi hakim dalam memilih sanksi pidana (jenis maupun berat-ringannya sanksi) dan harus ada kemungkinan modifikasi pidana (perubahan /penyesuaian) dalam pelaksanaannya. Jadi mengandung asas fleksibilitas dan asas modifikasi pidana".

Proses Individualisasi pelaku kejahatan, menurut Sheldon Glueck terdapat 4 (empat) prinsip yang mendas antara lain seperti: ${ }^{36}$ Pertama, "The treatment (sentence-imposing) feature of the proceedings must be sharply differentiated from the guilt-finding phase" (Perlakuan dari corak cara

33 Muladi dan Barda Nawawi Arief, Hlm. 32

34 Abdul Kholiq, Barda Nawawi Arief, Eko Soponyono, "Pidana Penjara Terbatas: Sebuah Gagasan dan Reorientasi Terhadap Kebijakan Formulasi Jenis Sanksi Hukum Pidana di Indonesia", Jurnal Law Reform, Volume 11, no. 1, (Maret 2015), Hlm. 111.

35 Barda Nawawi Arief. Bunga Rampai Kebijakan Hukum Pidana Perkembangan Penyusunan Konsep KUHP Baru, Edisi Ke Dua, (Semarang: Kencana, 2014), Hlm. 39

36 Sheldon Glueck, Principles of a Rational Code, Dalam Bukunya Stanley E. Grupp, Theories of Punisment, 1971, Hlm. 287-288. Dalam Barda Nawawi Arief. Bunga Rampai Kebijakan Hukum Pidana Perkembangan Penyusunan Konsep KUHP Baru, Edisi Ke Dua, (Semarang: Kencana, 2014), Hlm. 39-40. 
bekerja harus tajam dibedakan dari rasa bersalah yang menemukan tahap); Kedua, "The decisions as to treatment must be made by a boar or tribunal specially qualified in the interpretation and evaluation of psychiatric, psychological, and sociological data" (Keputusan seperti perlakuan harus dibuat oleh suatu pengadilan secara khusus yang memenuhi syarat dalam penafsiran dan evaluasi dari psikiatris, psikologis, dan data kemasyarakatan); Ketiga "The treatment must be modifiable in the light of scientific reports of progress" (Perlakuan harus dapat diubah, dipandang dari sudut laporan kemajuan ilmiah). Keempat "The right of the individual must be safeguarded against possible arbitraries or other unlawful action on the part of the treatment tribunal" (Hak individu harus dilindungi terhadap kemungkinan-kemungkinan keputusan pengadilan yang tidak bersalah).

Dalam Ide Individualisasi pidana menggunakan pendekatan humanistis yang mengacu terhadap prinsip-prinsip yang dimuat di dalam konsep individualisasi pidana, dimana setiap prinsip tersebut betul-betul mempertimbangkan/mengedepankan kepentingan dari pada warga binaan, tanpa mencederai tujuan dari pada pemidanaan itu sendiri. Dalam penggunaan sanksi pidana melalui pendekatan humanistis dapat membangkitkan kesadaran si pelanggar/pelaku tindak pidana akan nilai-nilai pergaulan hidup bermasyarakat dan nilai-nilai kemanusiaan. ${ }^{37}$ Individualisasi pidana kemudian diartikan sebagai "sebuah sistem pemidanaan yang lebih melihat kepada pertimbangan yang bersifat individual dan juga elastis atau dapat dimodifikasi/diubah /disesuaikan dengan perubahan dan perkembangan individu (terpidana) yang bersangkutan". ${ }^{38}$

Pokok pemikiran individualisasi pidana beriorientasi pada faktor "orang" (pelanggar/pelaku tindak pidana). tujuan individualisasi pidana terwujud dari norma umum pemidanaan antara lain:

Pertama, "tidak seorang pun yang melakukan tindak pidana tanpa adanya kesalahan/nulla poena sine culpa/Keine Strafe ohne Schuld"; Kedua, alasan penghapus pidana khusus mengenai alasan pemaaf, dimaksudkan sebagai masalah "error" (kesalahan), pembelaan terpaksa, daya paksa yang melampaui batas, dan tidak ada kemampuan bertanggungjawab dan anak yang berusia dibawah 12 tahun;

37 Sri Endah Wahyuningsih. Prinsip-prinsip Individualisasi Pidana dalam Hukum Pidana Islam dan Prospek Kontribusinya Bagi Pembaharuan Hukum Pidana Indonesia. Thesis, Semarang: Program Magister Ilmu Hukum UNDIP. 2002. Hal.38

38 Naskah Akademik Rancangan Undang-Undang Hukum Pidana, Hlm. 38 
Ketiga, Dalam pedoman pemidanaan hakim wajib mempertimbangkan beberapa faktor sebagaimana diatur dalam Pasal 54 ayat (1) RKUHP antara lain: "motif, sikap batin dan kesalahan si pembuat, cara si pembuat melakukan tindak pidana, riwayat hidup dan keadaan sosial ekonominya serta bagaimana pengaruh pidana terhadap masa depan pembuat tindak pidana, pengaruh tindak pidana terhadap korban maupun keluarga korban, pemaafan dari korban dan/atau keluarganya, dan/atau padangan masyarakat terhadap tindak pidana yang dilakukan."; 39 Empat, "dalam pedoman pemberian maaf/pengampunan, hakim mempertimbangkan faktor keadaan pribadi si pembuat dan pertimbangan segi kemanusiaan". Menurut Prof. Nyoman Serikat pengampunan hanya dapat diberikan kepada terpidana yang melakukan tindak pidana ringan atau yang di dalam RUU KUHP diancam dengan pidana penjara tidak lebih/dibawah satu tahun ${ }^{40}$;

Kelima, dalam ketentuan mengenai peringanan dan pemberatan pidana harus mempertimbangkan kepribadian si pelaku baik dari segi fisik, psikis dan perekonomian; keenam, dalam penjatuhan pidana kedepannya hakim akan diberikan lebih banyak opsi pemidanaan untuk mengurangi penggunaan sanksi pidana penjara, termasuk pemberian pidana tindakan; ketujuh, kedepannya hakim diperbolehkan untuk mengubah sanksi pidana yang telah berkekuatan hukum tetap sesuai dengan perubahan/ perkembangan/perbaikan pada diri terpidana setelah menjalani masa tahanan; dan kedelapan, apabila terjadi suatu tindak pidana, maka yang akan menanggung beban/bertanggung jawab atas tindakan yang telah dilakukan adalah pribadi/individu yang melakukan tindakan pidana tersebut dan pertanggungjawaban tersebut tidak dapat diwakilkan.

Bertolak dari pokok pikiran individualisasi pidana memberikan sebuah trobosan baru dalam sistem pemidanaan di Indonesia dimana hakim diberikan keleluasaan dalam memilih dan menentukan sanksi, baik itu pidana ataupun tindakan yang dianggap tepat atau sesuai bagi pelaku tindak pidana. Meskipun keleluasaan yang dimiliki ada batasanya, namun hakim tetap saja memiliki banyak opsi pemidanaan. Pola jenis sanksi pidana dalam RUU KUHP terdiri dari ${ }^{41}$ jenis "pidana" dan

39 Pasal 54 ayat (1) Rancangan Undang-Undang Hukum Pidana Konsep September 2019

40 Prof. Dr. Nyoman Serikat Putra Jaya, S.H., M.H. (Tim Panitia Terpadu RUU KUHP) Oleh Samuel Arsheldon. Fakultas Hukum Universitas Diponegoro Semarang. Tanggal 16 Maret 2020

41 Pasal 64 Rancangan Undang-Undang Hukum Pidana 
"tindakan" yang masing-masing terdiri dari "1) Pidana terdiri atas: a) Pidana pokok terdiri atas: Pidana Penjara; Pidana tutupan; Pidana pengawasan; Pidana denda; dan Pidana kerja sosial. b) Pidana tambahan terdiri atas: Pencabutan hak tertentu; Perampasan Barang tertentu dan/atau tagihan; Pengumuman putusan hakim; Pembayaran ganti rugi; Pencabutan izin tertentu; dan Pemenuhan kewajiban adat setempat". Sedangkan pidana yang bersifat khusus merupakan pidana mati yang selalu diancam secara alternative. 2) TINDAKAN yang dapat dikenakan bersama-sama dengan pidana pokok berupa; "Konseling; Rehabilitasi; Pelatihan kerja; Perawatan di lembaga; dan/atau Perbaikan akibat tindak pidana".

Rancangan Undang-Undang Hukum Pidana mengimplementasikan ide individualisasi pidana berupa elasticity of sentencing sebagai berikut: 42

Pertama, Dalam Konsep RKUHP sanksi yang dapat dijatuhkan berupa "pidana" (yaitu pidana pokok dan pidana tambahan), serta "tindakan". Namun dalam penerapannya hakim memiliki beberapa alternatif dalam menjatuhkan pidana yaitu: “a) Menjatuhkan pidana pokok saja; b) Menjatuhkan pidana tambahan saja; c) Menjatuhkan tindakan saja; d) Menjatuhkan pidana pokok dan pidana tambahan; e) Menjatuhkan pidana pokok dan tindakan; f) Menjatuhkan pidana pokok, pidana tambahan; dan g) Tindakan".

Kedua, Pada prinsipnya pidana dijatuhkan bagi pelaku tindak pidana sesuai dengan pidana pokok yang tercantum (diancamkan dalam rumusan delik yang bersangkutan dalam buku II), namun dalam konsep RUU KUHP hakim boleh menjatuhkan jenis sanksi baik pidana pokok atau pidana tambahan atau tindakan yang tidak tercantum, sepanjang dimungkinkan dan diperbolehkan menurut aturan umum Buku I RUU KUHP. Misalnya: Pidana yang tercantum/diancamkan adalah "pidana penjara", tetapi menurut Buku I hakim dapat menjatuhkan: a) "pidana tutupan" atau "pidana pengawasan" (Pasal 76 dan 77 RUU KUHP); b) "pidana denda" (apabila pidana penjara diancamkan secara tunggal, lihat Pasal 80 RUU KUHP); atau c) "pidana kerja sosial” (apabila hakim bermaksud menjatuhkan pidana penjara tidak lebih dari 6 bulan; lihat Pasal 86 RUU KUHP).

${ }^{42}$ Naskah Akademik Rancangan Undang-Undang Hukum Pidana 
Ketiga, Meskipun sanksi pidana diancamkan secara "tunggal", namun dalam penerapannya hakim diperbolehkan/diizinkan memilih pidana alternatif lainnya (lihat Pasal 57 dan 58 RUU KUHP). Keempat, Meskipun suatu tindak pidana diancamkan sanksi pidana secara "alternatif" namun dalam penerapannya hakim diperbolehkan menjatuhkan pidana secara kumulatif (lihat Pasal 59). Kelima, Pidana yang dijatuhkan sudah mempunyai keputusan hukum yang tetap tetapi dalam pelaksanaanya selalu diberikan ruang untuk melakukan perubahan/ penyesuaian kembali dan peninjauan terhadap sanksi pidana yang dijatuhkan (lihat Pasal 57).

Bertolak dari uraian di atas bahwa bahwa konsep individualisasi pidana dalam RKUHP juga menggunakan asas modifikasi dimana asas ini membuka peluang untuk dilakukannya perubahan/penyesuaian/ peninjauan kembali putusan pemidanaan yang diberikan oleh hakim yang telah berkekuatan hukum tetap (inkracht van gewijde) yang disesuaikan dengan perubahan/ perkembangan/ perbaikan pada diri pelaku tindak pidana sendiri dengan mempertimbangkan tujuan pemidanaan. Barda Nawawi Arief berpendapat "pelaksanaan modifikasi pidana kedepannya akan dilakukan dengan penilaian oleh hakim berdasarkan hasil laporan dari BAPAS (Balai Pemasyarakatan) dan juga kejaksaan terhadap warga binaan yang mengajukan permohonan modifikasi pidana. Laporan ini merupakan sebuah timbal balik (feedback) dari BAPAS dan kejaksaan kepada hakim, yang mana kedua lembaga tersebut berperan sebagai pihak yang melaksanakan putusan pidana. Selanjutnya harus ada aturan/syarat formal untuk membantu hakim menilai apakah seorang warga binaan layak untuk diberikan modifikasi pidana atau tidak. Apabila dianggap layak, maka kemudian hakim akan memberikan putusan sesuai dengan hasil penilaian hakim dan permohonan dari warga binaan tersebut. ${ }^{43}$

Nyoman Serikat Putra Jaya ${ }^{44}$ juga berpendapat untuk mengatasi permasalahan kelebihan kapasitas di lembaga pemasyarakatan, kedepannya penjatuhan pidana penjara oleh hakim bagi terpidana harus diberikan bagi pelaku tindak pidana berat atau serius, misalnya pem-

43 Prof. Dr. Barda Nawawi Arief, S.H. (Ketua Tim Buku I Penyusunan RUU KUHP)) Oleh Samuel Arsheldon dan Supriardoyo Simanjuntak. Semarang. Tanggal 10 Maret 2020

44 Samuel A.H.I. Siahaan. Kebijakan Kriminal Individualisasi Pidana tentang Strategi Mengurangi Kelebihan Kapasitas di Lembaga Pemasyarakatan. Skripsi, Semarang: Program Sarjana Hukum Universitas Diponegoro. 2020. HIm. 146 
bunuhan, korupsi, narkotika, terorisme, dan tindak pidana berat/serius lainnya. Kemudian, hakim harus mempertimbangkan opsi pemidanaan lain bagi terpidana selain pidana penjara, dengan kata lain pidana penjara tidak boleh lagi dijadikan seolah-olah sebagai "anak emas" dari pada pidana itu sendiri.

Mencermati pandangan para pakar hukum pidana sekaligus perumus RKUHP maka dapat disimpulkan bahwa keberhasilan konsep individualisasi pidana dalam mengatasi kelebihan kapasitas di lembaga pemasyarakatan tergantung terhadap hakim yang menjatuhkan putusan di persidangan kepada pelaku tindak pidana. Mengingat bahwa konsep individualisasi pidana hanyalah sebagai suatu pedoman bagi hakim dalam menjatuhkan pidana yang bermartabat dan sesuai dengan prinsip humanis tanpa menghilangkan rasa keadilan bagi korban tindak pidana. Sehingga dengan adanya konsep individualisasi pidana diharapkan dapat menghindari dijatuhkannya sanksi pidana yang dapat berakibat pada semakin meningkatnya over kapasitas di lembaga pemasyarakatan.

\section{SIMPULAN}

Kebijakan pemerintah dalam rangka menyelamatkan tahanan dan warga binaan pemasyarakatan di lapas dengan mengeluarkan "Permenkumham No.10 Tahun 2020 Tentang Syarat Pemberian Asimilasi dan Hak Integrasi Bagi Narapidana dan Anak dalam Rangka Pencegahan dan Penanggulangan Penyebaran COVID-19, dan Keputusan Menteri Hukum dan HAM No.19.PK.01.04 Tahun 2020 tentang Pengeluaran dan Pembebasan Narapidana Anak Melalui Asimilasi dan Integrasi dalam Rangka Pencegahan dan Penanggulangan Penyebaran COVID-19". Kebijakan ini hanya berlaku bagi narapidana dan anak yang melakukan tindak pidana umum. Namun Kebijakan Asimilasi dan Integrasi yang dikeluarkan menimbulkan keresahan dimasyarakat karena terdapat narapidana yang melakukan tindak pidana setelah dibebaskan dari Lapas. Atas dasar itu untuk memberikan rasa aman kepada masyarakat jika menerapkan kebijakan asimilasi dan integrasi maka harus memperketat syarat. Setidaknya terdapat dua syarat yang harus ditambah yaitu dalam pemberian asimilasi dan integrasi harus melibatkan hakim pengawas dan pengamat untuk dimintai pertimbangannya, dan Penakaran Resiko (Risk Assessment). 
Strategi Antisipasi Over Kapasitas di Lembaga Permasyarakatan sebagai Suatu Refleksi atas Kebijakan Pencegahan Penyebaran Covid-19, dalam Pembaharuan Hukum Pidana menganut dua konsep yang dimuat dalam RKUHP yaitu Tujuan Pemidanaan dan Individualisasi Pidana. Pertama, tujuan pemidanaan diarahkan kepada pengayoman masyarakat, perlindungan masyarakat (social defence), memasyarakatkan terpidana dengan melakukan pembimbingan, memulihkan dan menumbukan rasa penyelesalan dan rasa bersalah pada terpidana serta menciptakan keseimbangan antara masyarakat dan terpidana. Kedua, Ide Individualisasi Pidana yang berioerientasi terhadap pelaku tindak pidana yang manusiawi memperhatikan karakteristik pertanggungjawaban pidana bersifat pribadi, tiada pidana tanpa kesalahan, pidana disesuaikan dengan karakteristik dan kondisi sipelaku. Hal ini memberikan pemahaman bahwa harus ada kelonggaran/fleksibilas bagi hakim dalam memilih sanksi pidana (jenis maupun berat ringannya sanksi) mengingat hakim pada saat ini lebih cenderung menjatuhkan pidana penjara. Oleh karena itu dengan berlakunya RKUHP dimasa yang akan datang aparat penegak hukum sedapat mungkin tidak terburu buru menjatuhkan atau menuntut pelaku tindak pidana dengan pidana penjara karena dalam RKUHP banyak pilihan yang dapat dipilih oleh aparat penegak hukum dan tidak menghilangkan esensi perlindungan bagi masyarakat yang didalamnya termasuk korban tindak pidana.

\section{DAFTAR PUSTAKA}

Abdul Kholiq, Barda Nawawi Arief, Eko Soponyono, "Pidana Penjara Terbatas: Sebuah Gagasan dan Reorientasi Terhadap Kebijakan Formulasi Jenis Sanksi Hukum Pidana di Indonesia", Jurnal Law Reform, Volume. 11, no. 1, (Maret 2015).

Achmad Putra Perkasa, Rissang, "Optimalisasi Pembinaan Narapidana dalam Upaya Mengurangi Overcapacity Lembaga Pemasyarakatan", Jurnal Wajah Hukum, Volume 4 no 1, (April 2020)

Angkasa, "Over Capacity Narapidana di Lembaga Pemasyarakatan, Faktor Penyebab, Implikasi Negatif, serta Solusi dalam Upaya Optimalisasi Pembinaan Narapidana", Jurnal Dinamika Hukum, Volume 10, no. 3, (September 2010). 
Benuf, Kornelius dan Muhamad Azhar, "Metodologi Penelitian Hukum Sebagai Instrumen Instrumen Mengurangi Permasalahan Hukum Kontemporer", Jurnal Gema Keadilan, Volume 7, Edisi 1 (Juni 2020)

Cnnindonesia.com, 106 Napi Asimilasi Kembali Berulah, Mencuri Hingga Pencabulan, <https://www.cnnindonesia.com/nasional/2020051215032412-502544/106-napi-asimil asi-kembali-berulah-mencurihingga-pencabulan,> Diakses 15 Mei 2020.

Hamzah, Andi, Sistem Pidana dan Pemidanaan di Indonesia, Jakarta: Pradnya Paramita, 1993.

Harefa, Safaruddin "Kebijakan Kriminal Dalam Menanggulangi Kelebihan Kapasitas Lembaga Pemasyarakatan”, Jurnal Yuridis, Volume 5, No. 2, (November 2019).

Keputusan Presiden Republik Indonesia Nomor 12 Tahun 2020 Tentang Penetapan Bencana Nonalam Penyebaran Corona Virus Disease 2019 (Covid-19) Sebaga Bencana Nasional (SK No 010750 A)

Kitab Undang-Undang Hukum Pidana

Kompas.com "Sederet Kasus Napi yang Dibebaskan Kembali Berulah dan Ditangkap Polisi", <https://regional.kompas.com/read/ 2020/04/12/06100011/sederet-kasus-napi-yang-dibebaskankembali-berulah-dan-ditangkap-polisi> Diakses 18 Mei 2020 Kumparan.com, "39 Ribu Napi Dibebaskan karena Asimilasi Corona, 90 Orang Berulah Lagi”,<https://kumparan.com/kumparannews/ 39-ribu-napi-dibebaskan-karena-asimilasi-corona-95-orang-ber ulah-lagi-1tOSeawgtg6/full>, Diakses 15 Mei 2020.

Muladi dan Barda Nawawi Arief, Teori-Teori dan Kebijakan Pidana, Bandung: Alumni, 2010.

Muladi, Lembaga Pidana Bersyarat, Bandung: PT Alumni, 2004.

Mulyono, Galih Puji, Arief, Barda Nawawi. "Upaya Mengurangi Kepadatan Narapidana dalam Lembaga Pemasyarakatan di Indonesia", Jurnal Law Reform, Volume 12, no. 1, (Maret 2016).

Naskah Akademik Rancangan Undang-Undang Hukum Pidana 
Nawawi, Arief Barda. Bunga Rampai Kebijakan Hukum Pidana Perkembangan Penyusunan Konsep KUHP Baru, Edisi Ke Dua, Semarang: Kencana, 2014.

Tujuan dan Pedoman Pemidanaan (Perspektif Pembaharuan dan Perbandingan Hukum Pidana), Semarang: Pustaka Magister, 2017.

(Ketua Tim Buku I Penyusunan RUU KUHP)) Oleh Samuel Arsheldon dan Supriardoyo Simanjuntak. Semarang. Tanggal 10 Maret 2020.

Priyo Gunarto, Marcus, "Sikap Memidana yang beriorientasi Pada Tujuan Pemidanaan", Mimbar Hukum,Volume 21, no. 1, (Februari 2009).

Pusat Perencanaan Pembangunan Hukum Nasional, "Perencanaan Pembangunan Hukum Nasional Politik Hukum Pidana dan Sistem Pemidanaan, Jakarta: (2010)

Putra Jaya, Nyoman Serikat (Tim Panitia Terpadu RUU KUHP) Oleh Samuel Arsheldon. Fakultas Hukum Universitas Diponegoro Semarang. Tanggal 16 Maret 2020.

Rahardjo, Satjipto. Membedah hukum progresif, Jakarta: Penerbit Buku Kompas, 2006

Rancangan Undang-Undang Hukum Pidana Konsep September 2020

Rumadan, Ismail "Problem Lembaga Pemasyarakatan Di Indonesia Dan Reorientasi Tujuan Pemidanaan”, Jurnal Hukum dan Peradilan, Volume 2 no. 2, (Juli 2013)

Samuel A.H.I. Siahaan, Kebijakan Kriminal Individualisasi Pidana tentang Strategi Mengurangi Kelebihan Kapasitas di Lembaga Pemasyarakatan. Skripsi Sarjana Ilmu Hukum UNDIP. 2020.

Sistem Database Pemasyarakatan. Diakses melalui < http://smslap. ditjenpas.go.id/public/grl/ current/daily>

Sri Endah Wahyuningsih. Prinsip-prinsip Individualisasi Pidana dalam Hukum Pidana Islam dan Prospek Kontribusinya Bagi Pembaharuan Hukum Pidana Indonesia. Thesis Magister Ilmu Hukum UNDIP. 2002.

Surat Edaran Mahkamah Agung No. 7 Tahun 1985, tentang petunjuk Pelaksanaan Tugas Hakim Pengawas dan Pengamat. 
Susanto , I.S., Kriminologi, Yogyakarta: Genta Publishing, 2011.

TV One, "Napi Dibebaskan, Ahli Psikologi Forensik: Lapas Menjadi Tempat Aman untuk Isolasi Covid-19", https://www.youtube. com/watch?v=zi5zdcuWp0k, Diakses Tanggal 3 Mei 2020.

Undang-Undang NOmor 8 Tahun 1981 Tentang Kitab Undang Undang Hukum Acara Pidana (Lembaran Negara Republik Indonesia Nomor 76 dan Tambahan Lembaran Negara Republik Indonesia Tahun 1981 Nomor 3209. 